\title{
Diagnosing occupational COVID-19 in Croatian healthcare workers
}

\author{
Roko Žaja ${ }^{1}$, Ivana Kerner ${ }^{2}$, Milan Milošević1 ${ }^{1}$ and Jelena Macan ${ }^{3}$ \\ ${ }^{1}$ University of Zagreb School of Medicine, Andrija Štampar School of Public Health, Zagreb, Croatia \\ ${ }^{2}$ Bonifarm zdravlje, Zagreb, Croatia \\ ${ }^{3}$ Institute for Medical Research and Occupational Health, Zagreb, Croatia
}

[Received in October 2021; Similarity Check in October 2021; Accepted in December 2021]

Coronavirus disease 2019 (COVID-19) can be diagnosed as occupational disease by an occupational health physician $(\mathrm{OHP})$, if supported by relevant work-related and medical documentation. The aim of this study was to analyse such documentation submitted by Croatian healthcare workers (HCWs) and discuss its relevance in view of European and Croatian guidelines. The study included 100 Croatian HCWs who were SARS-CoV-2-positive and requested that their infection be diagnosed as occupational disease by their OHPs from 1 May 2020 to 10 March 2021. As participants they were asked to fill out our online Occupational COVID-19 in Healthcare Workers Questionnaire. For the purpose of this study we analysed answers about the type of close contact at the workplace, COVID-19 symptoms, and enclosed workrelated (job description, employer statement about exposure to SARS-CoV-2) and medical documentation (positive SARS-CoV-2 polymerase chain reaction test and patient history confirming the diagnosis of COVID-19). Most participants were working in hospitals $(\mathrm{N}=95)$, mostly nurses $(\mathrm{N}=75)$, who became infected by a patient $(\mathrm{N}=68)$ or colleague $(\mathrm{N}=31)$, and had at least one COVID-19 symptom ( $\mathrm{N}=87)$. Eighty participants did not enclose obligatory documents, 41 of whom failed to submit job description and 31 both job description and employer statement. These findings confirm that the major risk of occupational COVID-19 in HCWs is close contact with patients and colleagues, and points out the need for better cooperation between OHPs, occupational safety experts, employers, and diseased workers.

KEY WORDS: asymptomatic infection; guideline; job description; nurses; SARS-CoV-2

It is generally considered that coronavirus disease 2019 (COVID-19) should be recognised as occupational health disorder in workers who are at higher occupational risk of infection with severe acute respiratory syndrome coronavirus 2 (SARS-CoV-2) than the general population $(1,2)$, especially in view of Annex I, entry No. 407 of the Information notices on occupational diseases: a guide to diagnosis issued by the European Commission DirectorateGeneral for Employment, Social Affairs and Equal Opportunities (3).

Healthcare workers belong to the group of so-called essential workers who are at high occupational risk of SARS-CoV-2 infection (1), and as such, they should be covered by insurance accordingly and receive particular attention as they return to work $(1,4)$. However, there are noticeable procedural differences in recognising occupational COVID-19 and covering workers with insurance accordingly between countries. For instance, Slovenian (internal communication) and Italian (5) experts define COVID-19 acquired at work as occupational injury. In Croatia it is considered occupational disease (6), and in

Corresponding author: Roko Žaja, University of Zagreb School of Medicine, Andrija Štampar School of Public Health, Rockefellerova 4, 10000 Zagreb, Croatia, E-mail: roko.zaja@snz.hr
Germany it is defined as both (7). Some countries recognise and cover occupational COVID-19 only for selected occupations (7), while the Croatian Health Insurance Fund covers all workers at increased risk of SARS-CoV-2 infection in line with Article 3, item 45 Infectious or parasitic diseases caused by work in occupations with evidenced increased risk of infection of the List of Occupational Diseases Act (8).

At the beginning of the pandemic, in May 2020, the Croatian Society of Occupational Health $(\mathrm{CSOH})$ prepared the guidelines for reporting COVID-19 as occupational disease (9) and suggested a diagnostic protocol for recognising occupational COVID-19. The diagnostic procedure, according to the guidelines, begins with the verification of medical documents confirming COVID-19 in a patient and documents confirming that the established COVID-19 is associated with increased occupational risk of SARS-CoV-2 infection. The guidelines also specify which documents need to be submitted: positive laboratory test results, clinical findings, and occupational, medical, and epidemiological history or occupational risk assessment. The procedure to be completed requires good cooperation between the diseased HCW, employer, and occupational health physician (OHP). This Croatian guideline is fully in line with the later published Statement on COVID-19 as 
occupational disease by the Occupational Medicine Section of the European Union of Medical Specialists (UEMS) (2).

The aim of our study was to see how this procedure had been carried out in practice on a sample of HCWs from all over Croatia.

\section{PARTICIPANTS AND METHODS}

This study was part of a larger on-going survey collecting data from active Croatian HCWs who were SARS-CoV-2-positive during the COVID-19 pandemic and who contacted their OHP to recognise the infection as occupational disease between 1 May 2020 and 10 March 2021. Preliminary results from this survey analysing clinical characteristics of work-related COVID-19 were published earlier (10). This study included 100 Croatian HCWs from eight of the twenty-one Croatian counties, aged 18 to 65 years, who were isolated due to known close contact with a patient or colleague who had COVID-19 or with contagious biological material contaminated with SARSCoV-2.

Our collaborating OHPs who assessed workplace risk by taking their occupational history invited them to participate in the study and informed them about our online Occupational COVID-19 in Healthcare Workers Questionnaire. We compiled the questionnaire in Microsoft Forms $^{\circledR}$ and sent the link to OHPs via e-mail, who forwarded the link to their patients. Participants filled in their age, sex, job, affiliation, and number of days after they tested SARSCoV-2-positive for the first time. For the purpose of this study, we used a multiple-choice question about the type of close contact at the workplace (infected patient, infected colleague, contagious biological material contaminated with SARS-CoV-2), a yes/no question about having COVID-19 symptoms during isolation, and a question asking participants to check which of the supporting documentation on the list (in line with the $\mathrm{CSOH}$ guidelines) they did submit to their OHP (9). For the purpose of this study, we grouped the documents into two categories: basic (obligatory for diagnosing COVID-19 as occupational disease) and supplementary. Basic documentation included medical report(s) about COVID-19 [patient history confirming the diagnosis of COVID-19 and positive polymerase chain reaction (PCR) test report], job description, and employer statement about occupational exposure to SARS-CoV-2. Supplementary documentation intended to help distinguish occupational from nonoccupational exposure to SARS-CoV-2 included history of other diseases issued by a family physician, statement about which personal protective equipment (PPE) was used in which circumstances, a list of work-related tasks, days spent away from work (including isolation, sick leave, other leave days or business travel), workplace risk assessment by occupational safety experts, and business and personal travel statement.

The study was approved by the ethics committees of the Institute for Medical Research and Occupational Health (approval No. 100-21/20-19, class: 01-18/20-02-2/1) and Zagreb University School of Medicine (approval No. 38059-10106-20-111/160, class: 641-07/20-02/01). All

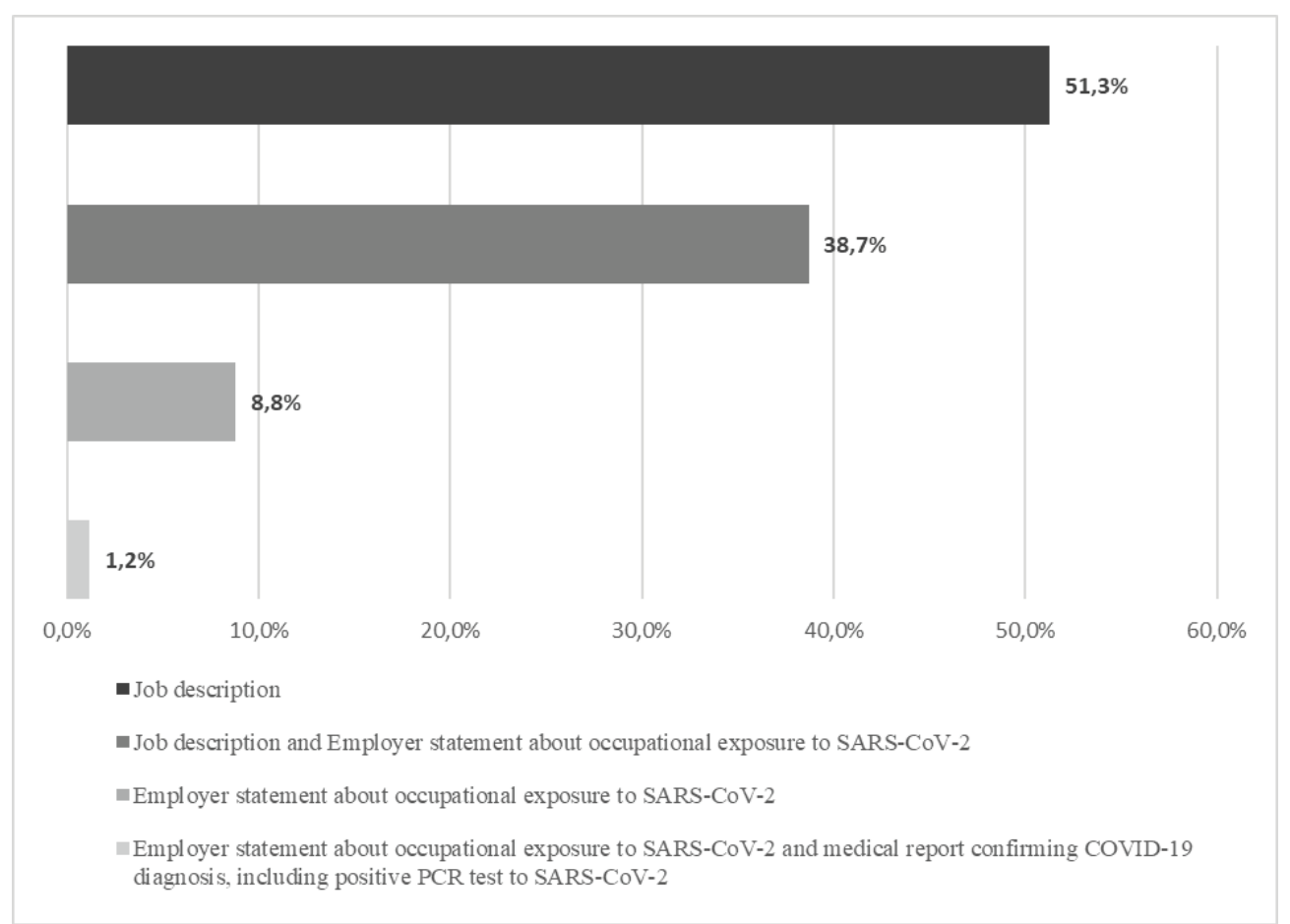

Figure 1 Missing documents for diagnosing occupational COVID-19 among the participants ( $\mathrm{N}=80)$ who did not submit complete basic documentation (medical report about COVID-19, job description, and employer statement about occupational exposure to SARSCoV-2) 
participants were included in the study after they signed informed consent which contained a GDPR statement.

\section{Statistical analysis}

The results were analysed with descriptive statistics using medians for continuous data and counts and percentages for categorical data. Differences between affiliations were analysed with Fisher's exact test (for categorical variables) to obtain odds ratios (ORs) with $95 \%$ confidential intervals ( $95 \% \mathrm{CIs}$ ). All P values below 0.05 were considered significant. All statistics were run on IBM SPSS Statistics for Windows, version 25.0 (IBM Corp., Armonk, NY, USA).

\section{RESULTS}

Table 1 shows general and epidemiological data about study participants $(\mathrm{N}=100)$. Most worked in hospitals $(\mathrm{N}=95)$ and were nurses $(\mathrm{N}=70)$. On average, they reported COVID-19 to their OHP 28.5 (interquartile range 1.3-45.0) days after they tested SARS-CoV-2-positive for the first time. Most were infected by a patient $(\mathrm{N}=68)$, and of those 59 used recommended PPE, while eight did not have it available, and one did not know which PPE was recommended. During isolation, most participants $(\mathrm{N}=87)$ had COVID-19 symptoms.

Table 2 shows which documents participants submitted to the OHP to support the claim of occupational COVID-19. All participants tested SARS-CoV-2 positive with the PCR test and most also submitted a medical report confirming the diagnosis of COVID-19 ( $\mathrm{N}=99)$, history of other diseases issued by a family physician $(\mathrm{N}=77)$, and employer's statement about occupational exposure to SARS-CoV-2 $(\mathrm{N}=61)$. Eighty participants did not submit complete basic documentation. Practically all of the missing basic documents needed to evidence the association between workplace exposure to SARS-CoV-2 infection and COVID-19 (job description and employer statement about occupational exposure to SARS-CoV-2). Half $(\mathrm{N}=41)$ of the participants with insufficient documentation lacked job description, and 31 did not submit either job description or employer statement. In that respect, participants working in clinical hospitals and clinical hospital centres were more careful to enclose employer's statement than those working in county general hospitals $(\mathrm{OR}=3.42 ; 95 \%$ CI 1.35-8.66, $\mathrm{P}<0.05$ ), who, in turn, were more careful to submit job description $(\mathrm{OR}=2.77 ; 95 \%$ CI 1.07-7.19, $\mathrm{P}<0.05)$.

\section{DISCUSSION}

Job description is a structured form (usually designated as 2-IN) (11) that gives general information about the worker, employer, job title, education, and working conditions (including hazards and job requirements). In order for the OHP to diagnose occupational COVID-19, job description should be supplemented with employer's statement confirming HCW's occupational exposure to SARS-CoV-2 $(2,9)$. Unfortunately, our study reveals glitches in communication between OHPs, employers, and diseased HCWs. One way to improve this communication is for OHPs to coordinate it with occupational safety experts at Occupational Safety and Health Committee meetings in order to streamline evidence of the occupational aetiology of a disease (12), as, currently, SARS-CoV-2 infection cannot be diagnosed or recognised as occupational without sufficient evidence of occupational exposure (9).

Addressing the varying criteria for recognising occupational COVID-19 between the EU member states,

Table 1 General and epidemiological characteristics of study participants $(\mathrm{N}=100)$

\begin{tabular}{|c|c|c|}
\hline & & $\mathbf{N}$ \\
\hline \multirow{3}{*}{ Job } & Nurses & 70 \\
\hline & Physicians & 19 \\
\hline & Others $^{\mathrm{a}}$ & 11 \\
\hline \multirow{2}{*}{ Gender } & Male & 21 \\
\hline & Female & 79 \\
\hline Age (years) & Median (IQR) & $47.0(36.0-55.0)$ \\
\hline \multirow{6}{*}{ Type of healthcare institution (affiliation) } & Clinical Hospital Centre & 55 \\
\hline & Clinical Hospital & 12 \\
\hline & County General Hospital & 27 \\
\hline & Special Hospital & 1 \\
\hline & Health Centre & 4 \\
\hline & Public Health Institute & 1 \\
\hline \multirow{3}{*}{ Close contact at the workplace } & Infected patient & 68 \\
\hline & Infected colleague & 31 \\
\hline & Contagious biological material & 1 \\
\hline
\end{tabular}

${ }^{a}$ physiotherapists, laboratory technicians, radiology engineers, occupational therapists, physicists; IQR - interquartile range 
Table 2 Documents submitted to OHP by participants ( $\mathrm{N}=100)$ to support claim for occupational COVID-19

\begin{tabular}{|c|c|c|}
\hline & & $\mathbf{N}$ \\
\hline \multirow{3}{*}{ Basic documentation } & Medical report confirming COVID-19 diagnosis, including positive PCR test to SARS-CoV-2 & 99 \\
\hline & Employer statement about occupational exposure to SARS-CoV-2 & 61 \\
\hline & Job description & 28 \\
\hline \multirow{7}{*}{$\begin{array}{l}\text { Supplementary } \\
\text { documentation }\end{array}$} & Family physician data on other diseases & 77 \\
\hline & Data on the use of PPE & 49 \\
\hline & List of completed work tasks & 32 \\
\hline & Attendance report evidencing days away from work* & 18 \\
\hline & Workplace risk assessment document & 14 \\
\hline & Personal travel statement & 13 \\
\hline & List of business trips & 4 \\
\hline
\end{tabular}

* including isolation, sick leave, other leave days, or business travel

the Occupational Medicine Section of the UEMS published the Statement on COVID-19 as occupational disease (2), in which it proposes minimum diagnostic criteria for every EU member state. The first is SARS-CoV-2-positive PCR test and respiratory COVID-19 symptoms. In other words, the statement implies that asymptomatic SARS-CoV-2 infection is not to be recognised as occupational disease/ injury. The second criterion is sufficient evidence of occupational exposure. This means that COVID-19 should be recognised as occupational disease/injury in all workers with evidenced increased risk of SARS-CoV-2 infection even if the worker does not (properly) use PPE. The third criterion is that exposure must precede health effects for $1-10$ days, and the fourth is that differential diagnosis must be considered.

We had 13 participants with asymptomatic SARS$\mathrm{CoV}-2$ infection who apparently do not meet the national and UEMS Statement criterion for occupational COVID-19. Workers with occupationally acquired asymptomatic SARS-CoV-2 infection are not allowed to go to work because of preventive measures, and national authorities are encouraged to find a way to supplement their personal income during isolation on some other basis than occupational disease (2). In Croatia, only the recognition of occupational COVID-19 entails full salary compensation for isolation (13), and so far the national health insurance body has been compensating asymptomatic HCWs as if they had occupational COVID-19.

Another issue to consider are possible long-term health impairments related to COVID-19 that should also be considered for compensation in persons with recognised occupational COVID-19. According to the Croatian obligatory health insurance regulation (14), these patients are entitled to a $100 \%$ refund for sick leaves but not for longer than 18 months. It is still unclear which long-term health consequences of COVID-19 will be compensated as occupational.

Our study is limited to self-reported information and we had no access to medical and workplace documentation but it clearly confirms earlier reports that close contact with diseased patients or colleagues brings the highest risk of occupational COVID-19 regardless of PPE usage, while contact with potentially contaminated biological samples seems to present a negligible risk. It has also brought to our attention issues with supporting documentation. Although medical and workplace documentation (evidencing higher risk of occupational exposure) are equally important in the diagnosis of occupational COVID-19, workplace documentation (employer's statement, job description) is often lacking, and there is much room left for procedural improvements. To do that, we need better cooperation between OHPs, occupational safety experts, employers, and diseased workers.

\section{Acknowledgements}

The authors wish to thank occupational health physicians Almenka Balenović, Helena Blažić, Dražen Bučan, Sonja Ćulibrk, Edisa Ercegović, Željko Lisac, Krunoslav Mikolašević, Mate Mustać, Tea Samardžić, Andrea Santini, Karolina Šimić Marinović, Goranka Škeva, and Mira Vukšić for recruiting healthcare workers in the study.

\section{Conflict of interests}

None to declare.

\section{REFERENCES}

1. Carlsten C, Gulati M, Hines S, Rose C, Scott K, Tarlo SM, Torén K, Sood A, de la Hoz RE. COVID-19 as an occupational disease. Am J Ind Med 2021;64:227-37. doi: 10.1002/ajim.23222

2. European Union of Medical Specialists (UEMS). Recognition on COVID-19 as occupational diseases [displayed 25 May 2021]. Available at https://uems-occupationalmedicine.org/ wp-content/uploads/2021/02/Statement-on-the-recognitionof-COVID-19-as-occupational-disease-UEMS-format.pdf

3. Publications Office of the European Union. Information notices on occupational diseases a guide to diagnosis, 2009 [displayed 25 May 2021]. Available at https://op.europa.eu/ en/publication-detail/-/publication/5d549879-7f75-4e89b737-e19f530d1236 
4. George R, George A. COVID-19 in South Africa: An occupational disease. S Afr Med J 2020;110(8):12985. PMID: 32880285

5. Chirico F, Magnavita N. COVID-19 infection in Italy: An occupational injury. S Afr Med J 2020;110(6):12944. PMID: 32880541

6. Registar profesionalnih bolesti [Occupational diseases register, in Croatian, displayed 10 December 2021]. Available at http://www.hzzzsr.hr/wp-content/uploads/2021/05/ Registar-profesionalnih-bolesti-za-2020.pdf

7. Nowak D, Ochmann U, Brandenburg S, Nienhaus A, Woltjen M. COVID-19 als Berufskrankheit oder Arbeitsunfall: Überlegungen zu Versicherungsschutz und Meldepflicht in der gesetzlichen Unfallversicherung [COVID-19 as an occupational disease or work-related accident: Considerations regarding insurance cover and reporting obligation in the statutory accident insurance, in Germany]. Dtsch Med Wochenschr 2021;146:198-204. doi: 10.1055/a-1341-7867

8. Zakon o listi profesionalnih bolesti [List of occupational diseases act, in Croatian]. Narodne novine 162/1998, 107/2007.

9. Guidelines for reporting COVID-19 as occupational disease. Abbreviations: COVID-19- Coronavirus disease-19; SARSCoV2- Severe acute respiratory syndrome- Coronavirus 2, 2020 [displayed 25 May 2021]. Available at https://www. hdmr.hr/Portals/0/userfiles/4/Smjernica_prijava $\% 20$ COVID\%20 PB eng final.pdf? ver=rx jJsERfcxD359PjM6MMg\%3d\%3d

10. Žaja R, Kerner I, Macan J, Milošević M. Characteristics of work-related COVID-19 in Croatian healthcare workers: a preliminary report. Arh Hig Rada Toksikol 2021;72:36-41. doi: 10.2478/aiht-2021-72-3530

11. Odluka o obliku i sadržaju obrasca o medicinskom vještačenju u mirovinskom osiguranju [Decision on the form and content of the medical expertise form in pension insurance, in Croatian]. Narodne novine 120/1999.

12. Zakon o zaštiti na radu [Worker protection act, in Croatian]. Narodne novine 71/2014, 118/2014, 154/2014, 94/2018, 96/2018.

13. Zakon o obveznom zdravstvenom osiguranju [Obligatory health insurance act, in Croatian]. Narodne novine 80/2013, 137/2013, 98/2019.

14. Pravilnik o pravima, uvjetima i načinu ostvarivanja prava iz obveznog zdravstvenog osiguranja u slučaju ozljede na radu i profesionalne bolesti [Policy on rights, conditions and manner of right achievement by obligatory health insurance in case of occupational injury and occupational disease, in Croatian]. Narodne novine 75/2014, 154/2014, 79/2015, $139 / 2015,105 / 2016,40 / 2017,66 / 2017,109 / 2017,132 / 2017$, $119 / 2018,41 / 2019,20 / 2020,39 / 2020$.

15. Abbas M, Robalo Nunes T, Martischang R, Zingg W, Iten A, Pittet D, Harbarth S. Nosocomial transmission and outbreaks of coronavirus disease 2019: the need to protect both patients and healthcare workers. Antimicrob Resist Infect Control 2021;10(1):7. doi: 10.1186/s13756-020-00875-7

16. Suárez-García I, Martínez de Aramayona López MJ, Sáez Vicente A, Lobo Abascal P. SARS-CoV-2 infection among healthcare workers in a hospital in Madrid, Spain. J Hosp Infect 2020;106:357-63. doi: 10.1016/j.jhin.2020.07.020

17. Schneider S, Piening B, Nouri-Pasovsky PA, Krüger AC, Gastmeier P, Aghdassi SJS. SARS-Coronavirus-2 cases in healthcare workers may not regularly originate from patient care: lessons from a university hospital on the underestimated risk of healthcare worker to healthcare worker transmission. Antimicrob Resist Infect Control 2020;9(1):192. doi: 10.1186/s13756-020-00848-w

18. Gómez-Ochoa SA, Franco OH, Rojas LZ, Raguindin PF, Roa-Díaz ZM, Wyssmann BM, Romero Guevara SL, Echeverría LE, Glisic M, Muka T. COVID-19 in health-care workers: A living systematic review and meta-analysis of prevalence, risk factors, clinical characteristics, and outcomes. Am J Epidemiol 2021;190:161-75. doi: 10.1093/ aje/kwaa191

19. Zheng C, Hafezi-Bakhtiari N, Cooper V, Davidsona H, Habibiad M, Rileya P, Breathnach A. Characteristics and transmission dynamics of COVID-19 in healthcare workers at a London teaching hospital. J Hosp Infect 2020;106:3259. doi: 10.1016/j.jhin.2020.07.025

20. Boškoski I, Gallo C, Wallace MB, Costamagna G. COVID-19 pandemic and personal protective equipment shortage: protective efficacy comparing masks and scientific methods for respirator reuse. Gastrointest Endosc 2020;92:519-23. doi: 10.1016/j.gie.2020.04.048

21. Toomey EC, Conway Y, Burton C, Smith S, Smalle M, Chan X-H S, Adisesh A, Tanveer S, Ross L, Thomson I, Devane $\mathrm{D}$, Greenhalgh T. Extended use or reuse of single-use surgical masks and filtering face-piece respirators during the coronavirus disease 2019 (COVID-19) pandemic: A rapid systematic review. Infect Control Hosp Epidemiol 2021;42:75-83. doi: 10.1017/ice.2020.1243

22. Nguyen LH, Drew DA, Joshi AD, Guo C-G, Ma W, Mehta RS, Sikavi DR, Lo C-H, Kwon S, Song M, Mucci LA, Stampfer MJ, Willett WC, Eliassen AH, Hart JE, Chavarro JE, Rich-Edwards JW, Davies R, Capdevila J, Lee KA, Lochlainn MN, Varsavsky T, Graham MS, Sudre CH, Cardoso MJ, Wolf J, Ourselin S, Steves CJ, Spector TD, Chan AT; On behalf of the COPE Consortium. Risk of COVID-19 among frontline healthcare workers and the general community: a prospective cohort study. Preprint. medRxiv 2020 [displayed 8 December 2021]. Available at https://www. medrxiv.org/content/10.1101/2020.04.29.20084111v6. article-metrics 


\section{Dijagnosticiranje profesionalne bolesti COVID-19 u hrvatskih zdravstvenih djelatnika}

Specijalist medicine rada može dijagnosticirati koronavirusnu bolest 2019 (COVID-19) kao profesionalnu bolest uz potrebnu radnu i medicinsku dokumentaciju. Cilj ovog istraživanja bio je analizirati dokumentaciju koju su predali hrvatski zdravstveni djelatnici i raspraviti njezin značaj iz perspektive europskih i hrvatskih smjernica. U istraživanje je bilo uključeno 100 hrvatskih zdravstvenih djelatnika koji su bili pozitivni na SARS-CoV-2 i koji su od 1. svibnja 2020. do 10. ožujka 2021. zatražili od mjerodavnih specijalista medicine rada da im se infekcija dijagnosticira kao profesionalna bolest. Kao sudionici istraživanja ispunili su virtualni upitnik Profesionalna bolest COVID-19 u hrvatskih zdravstvenih djelatnika. Analizirali smo odgovore o vrsti bliskoga kontakta na radnome mjestu, simptomima bolesti COVID-19 i predanoj radnoj (opis poslova, izjava poslodavca o izloženosti SARS-CoV-2) i medicinskoj (pozitivan test lančane reakcije polimeraze na SARS-CoV-2, povijest bolesti kojom se potvrđuje dijagnoza COVID-19) dokumentaciji. Većina sudionika radila je u bolnici $(\mathrm{N}=95)$, i to većinom sestre $(\mathrm{N}=75)$, koje je zarazio pacijent $(\mathrm{N}=68)$ ili suradnik $(\mathrm{N}=31)$, i imali su barem jedan simptom bolesti COVID-19 (N=87). Osamdeset sudionika nije predalo obveznu dokumentaciju, od kojih 41 nije predao opis poslova, a 31 ni opis poslova ni izjavu poslodavca. Ovi rezultati potvrđuju da najveći rizik od profesionalne bolesti COVID-19 u zdravstvenih djelatnika proizlazi iz bliskoga kontakta s pacijentima i suradnicima te ističu potrebu za boljom suradnjom između specijalista medicine rada, stručnjaka za zaštitu na radu, poslodavaca i oboljelih radnika.

KLJUČNE RIJEČI: asimptomatska infekcija; medicinske sestre; opis poslova; SARS-CoV-2; smjernica 